\title{
Oxidation of Bis(2-hydroxy-1-naphthyl)methane and Similar Bisnaphthols with 2,3-Dichloro-5,6-dicyano-1,4-benzoquinone. Structure and Synthesis of Novel Products
}

\author{
Tirumalai R. Kasturi," Betageri Rajasekhar, Gonibella J. Raju, Gowravaram \\ Madhusudhan Reddy, Ramamoorthy Sivaramakrishnan, Narayanan Ramasubbu, and Kailasam \\ Venkatesan \\ Department of Organic Chemistry, Indian Institute of Science, Bangalore 560012, India
}

Oxidation of bis(2-hydroxy-1-naphthyl)methane (4a) with 2,3-dichloro-5,6-dicyano-1,4-benzoquinone (DDQ) has been shown to give the novel compounds, cis- and trans-dispiro naphthalene-

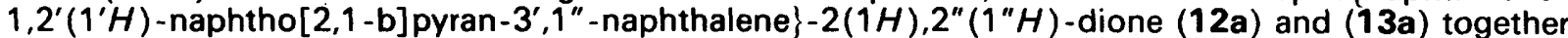
with the quinone methide dimer (6a) and the spiroketone (5a). Compounds (12a) and (13a) were characterised on the basis of their spectral properties and the structures were finally confirmed by an $X$ ray crystal structure analysis of (12a). Hydrogenation of compounds (12a) and (13a) has been shown to give the dihydroxy compound (14) via $\mathrm{C}-\mathrm{C}$ bond cleavage. An alternative synthesis of the dispironaphthalenones (12a) and (13a) was achieved by oxidation of the dihydroxy compound (14), prepared by an independent method. The generality of the oxidation of bisnaphthols of type (4a) to give novel products of the type (12a) and (13a) has been shown by studying the oxidation of the variously substituted bisnaphthols ( $4 b-d, f)$ with DDQ. A mechanism has been proposed invoking the intermediacy of the quinol ethers (22) and (24).

We have reported that ${ }^{1}$ oxidation of the oxydiphenol (1) with tetrachloro- $o$-benzoquinone (o-chloranil) gives a mixture of two isomeric spiro products (2) and (3). Compound (3) results from normal oxidative coupling, whereas (2) results from an unusual rearrangement. With a view to understanding the generality and mechanism of this rearrangement, the reaction of bis(2-hydroxy-1-naphthyl)methane (4a) with $o$-chloranil was studied. ${ }^{2}$ Interestingly this reaction gave the products $(5 \mathbf{a}),(6 \mathbf{a})$, and (7) along with (2) and (3). + A mechanism was proposed to explain the formation of these products invoking the intermediacy of the quinol ether (8) which disproportionates to give the oxydiphenol (1) and 1,2-naphthoquinone 1-methide (9). However, this mechanism could not be substantiated, since the oxydiphenol (1) could not be isolated from the reaction. We thought that oxidation of the bisnaphthol (4a) with 2,3dichloro-5,6-dicyano-1,4-benzoquinone (DDQ) would throw more light on the mechanism. Hence this reaction was studied and the results are discussed in this paper.

The reaction of the bisnaphthol (4a) with DDQ (1:1 molar ratio) was carried out in refluxing dry benzene. The resulting reaction mixture was concentrated and chromatographed, over neutral alumina. Elution with benzene gave the known spiroketone (5a) and the naphthoquinone methide dimer (6a). Further elution with chloroform gave a dark yellow solution from which two yellow compounds were isolated. The major product showed a molecular ion peak at $m / z$ 440. High resolution mass spectrometry indicated an elemental composition of $\mathrm{C}_{31} \mathrm{H}_{20} \mathrm{O}_{3}$ for this molecule. The i.r. spectrum of this compound showed the presence of two conjugated carbonyl groups $\left(v_{\max } .1690\right.$ and $\left.1670 \mathrm{~cm}^{-1}\right)$. The significant features of ${ }^{1} \mathrm{H}$ n.m.r. spectrum are: (i) the presence of non-equivalent methylene protons as shown by the coupling constants of the two upfield doublets ( $\delta 3.27$ and 4.29) and (ii) the presence of two doublets at $\delta 5.83$ and 6.0 which are not mutually coupled (double irradiation experiments) probably due to two $\alpha$-protons of the enone systems. These spectral data indicated the presence of two $\alpha, \beta$-unsaturated carbonyl groups. To obtain further

† The numbering used for compounds (5) and (6) is not systematic but is used for consistency with compounds (12) and (13).
Table 1. ${ }^{13} \mathrm{C}$ Chemical shifts of the compounds (13a), (6a), and (5a) ${ }^{a}$

\begin{tabular}{|c|c|c|c|}
\hline \multirow[b]{2}{*}{ C-Atom } & \multicolumn{3}{|c|}{ Compound } \\
\hline & (13a) & (6a) & $(5 \mathbf{a})$ \\
\hline C-1" & $82.42(\mathrm{~s})$ & $82.55(\mathrm{~s})$ & 89.33(s) \\
\hline C-2" & $199.16(\mathrm{~s})$ & $200.00(\mathrm{~s})$ & 197.34(s) \\
\hline C-3" & $123.54(\mathrm{~d})$ & 121.89 (d) & $122.69(\mathrm{~d})$ \\
\hline C-4" & $144.85(d)$ & 143.99 (d) & 145.29 (d) \\
\hline$C-4 a^{\prime \prime}$ & $132.10(\mathrm{~s})$ & $128.00(\mathrm{~s})$ & $130.69(\mathrm{~s})$ \\
\hline$C-5^{\prime \prime}$ & $128.69(\mathrm{~d})$ & $128.49(\mathrm{~d})$ & $128.86(d)$ \\
\hline C-6" & $127.77(\mathrm{~d})$ & $128.34(d)$ & $128.76(d)$ \\
\hline C-7" & $129.39(\mathrm{~d})$ & $129.42(d)$ & 129.49 (d) \\
\hline C-8" & $126.40(d)$ & $130.35(d)$ & $129.83(\mathrm{~d})$ \\
\hline C-8 $a^{\prime \prime}$ & $140.27(\mathrm{~s})$ & $143.84(\mathrm{~s})$ & $143.46(\mathrm{~s})$ \\
\hline C-1' & $26.58(\mathrm{t})$ & $33.48(t)$ & $42.88(t)$ \\
\hline C-2' & - & $18.22(\mathrm{t})$ & - \\
\hline$C-4 a^{\prime}$ & $152.00(\mathrm{~s})$ & $152.55(\mathrm{~s})$ & $157.81(\mathrm{~s})$ \\
\hline$C-5^{\prime}$ & $117.47(\mathrm{~d})$ & $118.54(\mathrm{~d})$ & $115.21(d)$ \\
\hline$C-6^{\prime}$ & $129.12(d)$ & $126.29(\mathrm{~d})$ & 126.92 (d) \\
\hline$C-6 a^{\prime}$ & $127.40(\mathrm{~s})$ & $129.08(\mathrm{~s})$ & $128.33(\mathrm{~s})$ \\
\hline$C-7^{\prime}$ & $128.69(\mathrm{~d})$ & $128.065(\mathrm{~d})$ & $128.76(d)$ \\
\hline C-8 ${ }^{\prime}$ & $129.48(\mathrm{~d})$ & 123.229 (d) & $123.26(d)$ \\
\hline C- $9^{\prime}$ & $127.78(\mathrm{~d})$ & $125.95(\mathrm{~d})$ & $125.58(\mathrm{~d})$ \\
\hline$C-10^{\prime}$ & 126.40 (d) & $123.50(\mathrm{~d})$ & 123.69 (d) \\
\hline$C-10 a^{\prime}$ & $132.17(\mathrm{~s})$ & $132.56(\mathrm{~s})$ & $130.83(\mathrm{~s})$ \\
\hline$C-10 b^{\prime}$ & $113.94(\mathrm{~s})$ & $112.28(\mathrm{~s})$ & $111.87(\mathrm{~s})$ \\
\hline C-1 & $56.08(\mathrm{~s})$ & & \\
\hline C-2 & $200.04(\mathrm{~s})$ & & \\
\hline C-3 & $122.17(\mathrm{~d})$ & & \\
\hline C-4 & $141.40(\mathrm{~d})$ & & \\
\hline C- $4 a$ & $131.74(\mathrm{~s})$ & & \\
\hline C-5 & $128.69(\mathrm{~d})$ & & \\
\hline$C-6$ & $126.10(\mathrm{~d})$ & & \\
\hline C-7 & $129.97(\mathrm{~d})$ & & \\
\hline C-8 & $127.93(d)$ & & \\
\hline$C-8 a$ & $136.60(\mathrm{~s})$ & & \\
\hline
\end{tabular}

a The letters in the parentheses indicate the nature of the signal in the offresonance decoupled spectrum; very similar values may be interchanged.

details of the structure, the ${ }^{13} \mathrm{C}$ n.m.r. spectrum of this compound (Table 1) was studied. The spectrum showed the presence of two carbonyl groups, and three $\mathrm{sp}^{3}$ carbon atoms; one $\mathrm{CH}_{2}$ and two bearing no $\mathrm{H}$-atoms. A comparison of the ${ }^{13} \mathrm{C}$ 
<smiles>Oc1ccc2ccccc2c1Oc1ccc(Cl)cc1Cl</smiles>

(1)

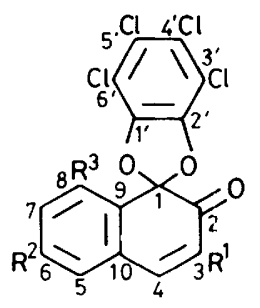

(3)

a; $R^{1}=R^{2}=R^{3}=H$

b; $R^{2}=R^{3}=H, R^{1}=M e$

c) $R^{1}=R^{3}=H, R^{2}=O M e$

d; $R^{1}=R^{2}=H, R^{3}=M e$

e; $R^{1}=R^{2}=H \cdot R^{3}=P r^{i}$

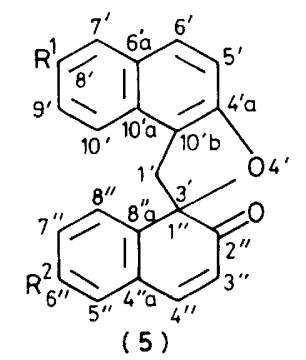

a ; $R^{1}=R^{2}=H$

b; $R^{1}=R^{2}=B r$

c: $R^{1}=R^{2}=B u^{t}$

d: $R^{1}=R^{2}=O M e$

e: $R^{\prime}=R^{2}=C N$<smiles>O=C1c2ccccc2C=CC12Oc1ccccc1O2</smiles>

(2)<smiles></smiles>

(4)

a; $R^{1}-R^{2}=H$

b; $R^{1}=R^{2}=B r$

c; $R^{1}=R^{2}=B u^{t}$

d: $R^{1}=R^{2}=O M e$

e: $R^{1}=R^{2}=C N$

f: $R^{1}=H, R^{2}=B r$

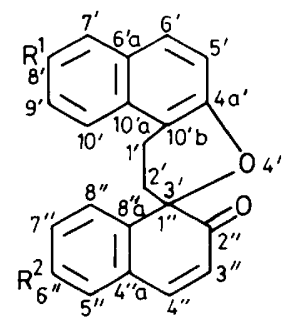

(6)
a; $R^{1}=R^{2}=H$
b: $\mathrm{R}^{1}=\mathrm{R}^{2}=\mathrm{Br}$
c: $R^{1}=R^{2}=B u^{t}$
d; $R^{1}=R^{2}=O M e$
e: $R^{1}=H, R^{2}=B r$<smiles>O=C1C=Cc2ccccc2C12COc1c(Cl)cccc1O2</smiles>

(7)<smiles>O=C1C=Cc2ccccc2C1(Cc1c(O)ccc2ccccc12)OC(O)=C(Cl)Cl</smiles>

(8)<smiles>C=C1C(=O)C=Cc2ccccc21</smiles>

(9)<smiles>CC1(C)Cc2c(ccc3ccccc23)OC12C(=O)C=Cc1ccccc12</smiles><smiles>CC12CCCC1(C)c1ccccc1C=CC2=O</smiles>

(10)

(11)

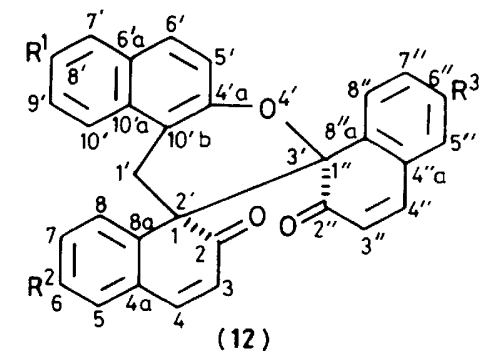

a; $R^{1}=R^{2}=R^{3}=H$

b; $R^{1}=R^{2}=R^{3}=B r$

c; $R^{1}=R^{2}=R^{3}=B u^{t}$

d: $R^{1}=R^{2}=R^{3}=O M e$

e; $R^{1}=B r, \quad R^{2}=R^{3}=H$

f: $R^{1}=R^{3}=B r, \quad R^{2}=H$

g: $R^{1}=R^{2}=B r, \quad R^{3}=H$

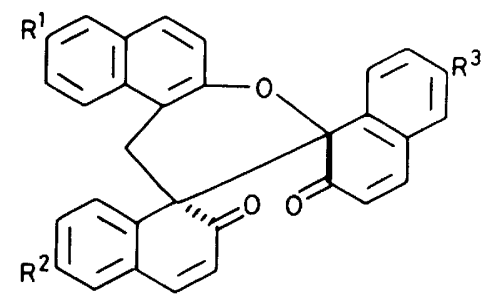

(13)

a; $R^{1}=R^{2}=R^{3}=H$

b; $R^{1}=R^{2}=R^{3}=B r$

c: $R^{1}=R^{2}=R^{3}=B u^{t}$

chemical shift values of this compound with those of the spiro compounds (5a) and (6a) (Table 1) indicated the presence of fragment (10) in this molecule. The similarity between the u.v. spectrum of this compound and that of (6a) (see Experimental section) further supported this. Comparison of the ${ }^{13} \mathrm{C}$ n.m.r. spectra of the $\beta$-dienones (3) containing the $\beta$-spirodienone moiety of type (11) (Table 2) confirmed the presence of such a moiety in this compound. Structure (12a), which was assigned to this compound on the basis of the above spectral data, was finally confirmed by an $X$-ray crystal structure analysis. ${ }^{3}$ The positional co-ordinates corresponding to an $R$-value of 0.117 are available from the Cambridge Crystallographic Data Centre.* Figure 1 shows a perspective view of the molecule and it may be seen that the two carbonyl groups face the same side. In other words, the molecule has $R, R$ or $S, S$ configuration (cisconfiguration), the torsion angle $\mathrm{C}(2)-\mathrm{C}(1)-\mathrm{C}\left(1^{\prime \prime}\right)-\mathrm{C}\left(2^{\prime \prime}\right)$ being $51.4^{\circ}$

\footnotetext{
* See details for obtaining these in ref. 3 .
} 
Table 2. ${ }^{13} \mathrm{C}$ Chemical shifts of the $\beta$-dienones (3) ${ }^{a}$

\begin{tabular}{cccccc} 
C- & \multicolumn{5}{c}{ Compound } \\
\cline { 2 - 6 } Atom & $(3 \mathbf{3})$ & $(\mathbf{3 b})$ & $(3 \mathbf{c})$ & $(\mathbf{3 d})$ & $(3 \mathbf{3 e})$ \\
C-1 & $106.400(\mathrm{~s})$ & $106,820(\mathrm{~s})$ & $106.800(\mathrm{~s})$ & $106.800(\mathrm{~s})$ & $106.800(\mathrm{~s})$ \\
C-2 & $188.145(\mathrm{~s})$ & $189.013(\mathrm{~s})$ & $188.269(\mathrm{~s})$ & $189.000(\mathrm{~s})$ & $188.390(\mathrm{~s})$ \\
C-3 & $123.040(\mathrm{~d})$ & $131.382(\mathrm{~s})$ & $123.694(\mathrm{~d})$ & $123.800(\mathrm{~d})$ & $122.051(\mathrm{~d})$ \\
C-4 & $145.859(\mathrm{~d})$ & $142.400(\mathrm{~d})$ & $145.642(\mathrm{~d})$ & $146.900(\mathrm{~d})$ & $147.967(\mathrm{~d})$ \\
C-5 & $130.204(\mathrm{~d})$ & $128.685(\mathrm{~d})$ & $115.478(\mathrm{~d})$ & $127.310(\mathrm{~d})$ & $129.181(\mathrm{~d})$ \\
C-6 & $128.902(\mathrm{~d})$ & $129.894(\mathrm{~d})$ & $162.817(\mathrm{~s})$ & $130.020(\mathrm{~d})$ & $130.204(\mathrm{~d})$ \\
C-7 & $131.010(\mathrm{~d})$ & $129.274(\mathrm{~d})$ & $116.284(\mathrm{~d})$ & $131.940(\mathrm{~d})$ & $132.312(\mathrm{~d})$ \\
C-8 & $132.374(\mathrm{~d})$ & $132.343(\mathrm{~d})$ & $130.790(\mathrm{~d})$ & $139.200(\mathrm{~s})$ & $154.416(\mathrm{~s})$ \\
C-9 & $144.650(\mathrm{~s})$ & $144.890(\mathrm{~s})$ & $144.805(\mathrm{~s})$ & $144.800(\mathrm{~s})$ & $145.270(\mathrm{~s})$ \\
C-10 & $131.196(\mathrm{~s})$ & $131.782(\mathrm{~s})$ & $125.400(\mathrm{~s})$ & $130.030(\mathrm{~s})$ & $129.367(\mathrm{~s})$ \\
C-1' & $133.862(\mathrm{~s})$ & $133.242(\mathrm{~s})$ & $132.770(\mathrm{~s})$ & $132.033(\mathrm{~s})$ & $132.033(\mathrm{~s})$ \\
C-2' & $133.862(\mathrm{~s})$ & $133.242(\mathrm{~s})$ & $132.770(\mathrm{~s})$ & $132.033(\mathrm{~s})$ & $132.033(\mathrm{~s})$ \\
C-3' & $112.874(\mathrm{~s})$ & $112.874(\mathrm{~s})$ & $112.812(\mathrm{~s})$ & $112.900(\mathrm{~s})$ & $112.905(\mathrm{~s})$ \\
C-4' & $125.950(\mathrm{~s})$ & $125.895(\mathrm{~s})$ & $125.833(\mathrm{~s})$ & $125.850(\mathrm{~s})$ & $125.926(\mathrm{~s})$ \\
C-5' & $125.950(\mathrm{~s})$ & $125.895(\mathrm{~s})$ & $125.833(\mathrm{~s})$ & $125.850(\mathrm{~s})$ & $125.926(\mathrm{~s})$ \\
C-6' & $112.874(\mathrm{~s})$ & $112.874(\mathrm{~s})$ & $112.812(\mathrm{~s})$ & $112.900(\mathrm{~s})$ & $112.905(\mathrm{~s})$
\end{tabular}

a The letters in parentheses indicate the nature of the signal in the offresonance decoupled spectrum.

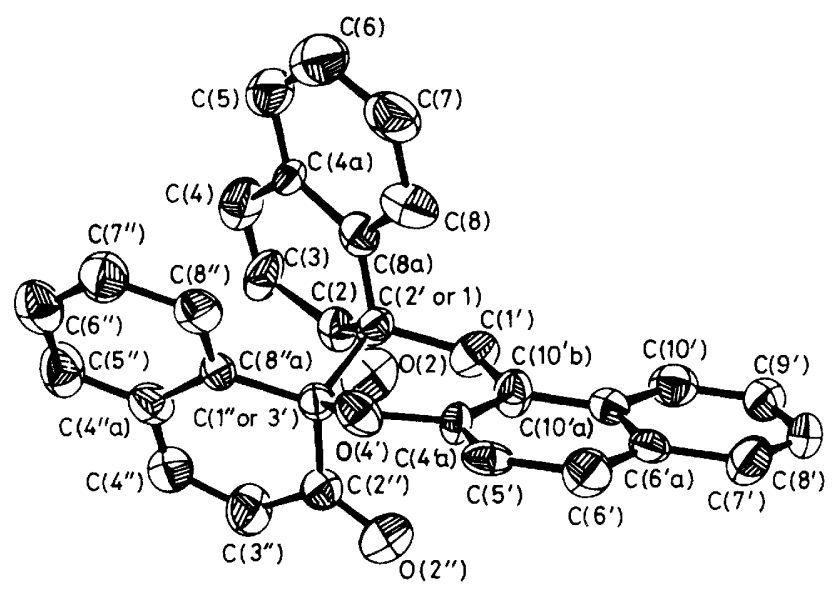

Figure 1. A perspective view of molecule (12a)

The other compound which was isolated in trace amounts from the chloroform fraction shows spectral (i.r., n.m.r., mass) properties similar to those of compound (12a). In addition, both compounds on hydrogenation with $10 \% \mathrm{Pd}-\mathrm{C}$ gave the same dihydroxy derivative (vide supra) indicating that this compound could be the diastereoisomer of (12a), i.e. it should have $R, S$ or $S, R$ configuration (trans-configuration). Hence, the structure of this compound can be represented as (13a).

Catalytic hydrogenation of the both cis- and trans-dispironaphthalenones (12a) and (13a) with $10 \% \mathrm{Pd}-\mathrm{C}$ gives a dihydroxy derivative $\left(M^{+} 442\right)$ identified as 1-[(2-hydroxy-1naphthyl)methyl]-2-(2-hydroxy-1-naphthyloxy)naphthalene (14). This is apparently formed by cleavage of the $\mathrm{C}\left(2^{\prime}\right) \mathrm{C}-\left(3^{\prime}\right)$ bond * instead of the $\mathrm{C}\left(3^{\prime}\right)-\mathrm{O}$ bond $\dagger$ which would lead to the dihydroxy compound (14). Interestingly the $\mathrm{C}\left(2^{\prime}\right)-\mathrm{C}\left(3^{\prime}\right)$ bond is found to be unexpectedly long $1.616(15) \mathrm{A}^{\circ}$ [cf. normal $\mathrm{C}\left(\mathrm{sp}^{3}\right)-\mathrm{C}\left(\mathrm{sp}^{3}\right)$ value of $\left.1.541 \mathrm{~A}^{\circ}\right] .^{4}$ This is consistent with the easy cleavage of this bond. Reduction of (12a) with zinc and

* Such carbon-carbon bond cleavage during catalytic hydrogenation has been reported; W. Riedl and J. Nickl, Chem. Ber., 1956, 89, 1838.

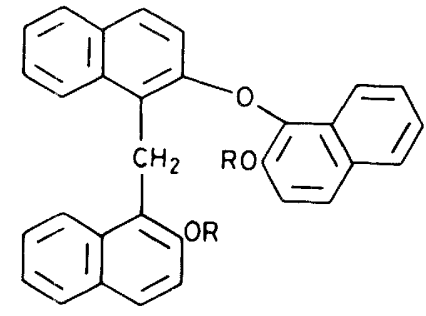

(14) $R=H$

(15) $\mathrm{R}=\mathrm{Me}$

(16) $\mathrm{R}=\mathrm{CH}_{2} \mathrm{Ph}$<smiles>[R]c1ccc2ccccc2c1Cc1cccc2ccccc12</smiles>

(18) $\mathrm{R}=\mathrm{CH}_{2} \mathrm{Ph}$

(19) $R=M e$<smiles>O=C1C=Cc2ccccc2C1(Cc1c(O)ccc2ccccc12)c1c(O)ccc2ccccc12</smiles>

(17)

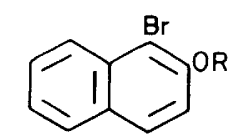

(20) $\mathrm{R}=\mathrm{CH}_{2} \mathrm{Ph}$

(21) $R=M e$ acetic acid also gave the same dihydroxy compound (14) (mixed m.p., and i.r. and ${ }^{1} \mathrm{H}$ n.m.r. spectra), through the cleavage of the $\mathrm{C}\left(2^{\prime}\right)-\mathrm{C}\left(3^{\prime}\right)$ bond. The presence of two hydroxy groups in (14) was confirmed by converting it into the corresponding dimethyl ether (15) and dibenzyl ether (16). The structure of the dihydroxy compound (14) is indicated by its spectral data and by the spectral data of its dimethyl and dibenzyl ethers; we confirmed its structure by an unambiguous synthesis (see below). Further, the oxidation of the dihydroxy compound (14) by any phenol oxidising agent should furnish the dispironaphthalenones (12a) and (13a). Thus (14) is an alternate intermediate for the synthesis of (12a) and (13a).

The most convenient synthetic precursor to (14) was thought to be the dimethyl ether or dibenzyl ether. As compound (14) decomposes near its melting point $\left(127-128^{\circ} \mathrm{C}\right)$ it would be necessary to remove the protecting groups at low temperatures. An attempt to synthesise the dibenzyl ether (which could be debenzylated at room temperature by $\mathrm{Pd}-\mathrm{C}$ hydrogenation) by Ullmann condensation of (18) ${ }^{5}$ and (20) failed. However, the reaction between bis(2-hydroxy-1-naphthyl)methane monomethyl ether (19) ${ }^{6}$ and 1 bromo-2-methoxynaphthalene (21) gave the expected dimethyl ether (15) in $25 \%$ yield. The dimethyl ether was identical with that obtained by methylation of the dihydroxy compound (14). As already mentioned, since the dihydroxy compound decomposes near $127^{\circ} \mathrm{C}$, the readily available demethylating agents $\mathrm{HBr}-\mathrm{AcOH}$ or pyridine- $\mathrm{HCl}$ could not be used. However, demethylation was achieved using boron tribromide, although, in poor yield. The demethylated compound was found to be identical (m.p., i.r. and n.m.r. spectra, and t.l.c.) with the dihydroxy compound (14). Oxidation of the dihydroxy compound with active manganese di-

† Similar spironaphthalenones of type (3), (5), and (6) have been shown to undergo $\mathrm{C}-\mathrm{O}$ bond cleavage on hydrogenation with $\mathrm{Pd}-\mathrm{C}(10 \%)$ to give the corresponding dihydroxy compounds; ref. 1; T. R. Kasturi, K. B. Ganesha Prasad, and B. Rajashekar, Indian J. Chem., Sect. B, 1982, 21, 813; F. M. Dean and D. A. Matkin, J. Chem. Soc., Perkin Trans. 1, 1977, 2289; T. R. Kasturi and G. Madhusudhan Reddy, unpublished results. 
<smiles>Oc1ccc2ccccc2c1Cc1cccc2ccccc12</smiles>

(4a)<smiles>N#Cc1cc(Oc2c(O)ccc3ccccc23)ccc1Cl</smiles>

(23)

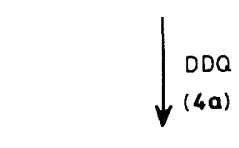

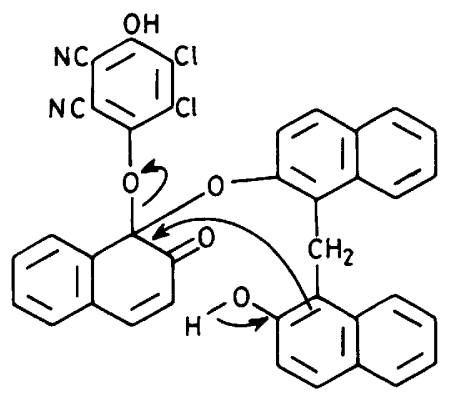

(24)

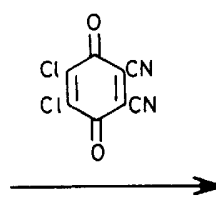

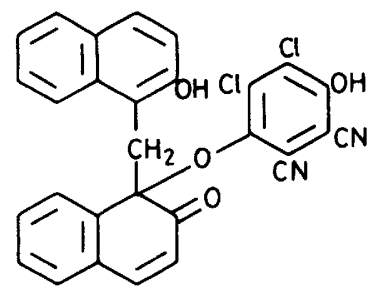<smiles>CCCCCCCC</smiles><smiles>Cc1c(O)ccc2ccccc12</smiles>

(5a)
(22)

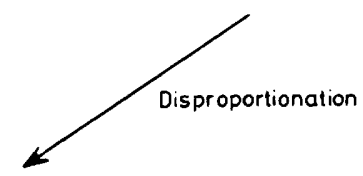<smiles>O=C1C=Cc2ccccc2C1=O</smiles>

Dimerisation (6a)<smiles>N#Cc1cc(Cl)cc(Cl)c1O</smiles><smiles>Cc1cccc2ccccc12</smiles>

$\mathrm{OH}$

(9)

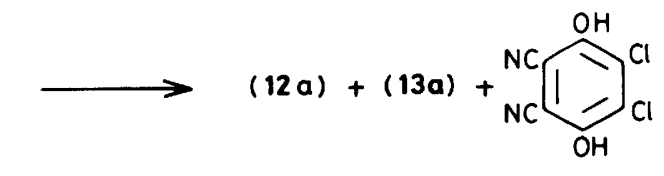

Scheme 1.

oxide gave a nearly quantitative yield of a yellow compound identical with the cis-dispironaphthalenone (12a). Oxidation with DDQ in refluxing dry benzene also gave mainly the cisdispironaphthalenone (12a) along with a trace of the transisomer (13a). This further confirmed the structures of (12a) and (13a) as well as of the dihydroxy compound (14).

To study the generality of this reaction, the oxidation of the bisnaphthols (4b-f) was undertaken and the results are summarised in Table 3. Similar results were observed in all cases, except for the cyanobisnaphthol (4e). Oxidation of (4b) and (4c) gave the expected quinonemethide dimers (6b) and (6c), the spiroketones (5b) and (5c), and the cis-dispironaphthalenones (12b) and (12c) together with traces of the trans-isomers (13b) and (13c), respectively. In the oxidation of the methoxybisnaphthol (4d) the yield of cis-dispironaphthalenone (12d) was low; and the trans-isomer could not be isolated. Oxidation of the monobromobisnaphthol (4I) gave the monobromodispironaphthalenone (12e) and the dibromodispironapthalenone (12f). A $1: 1$ mixture of the bisnaphthols (4a) and (4b) on oxidation with DDQ gave the dibromodispironaphthalenone (12g) along with

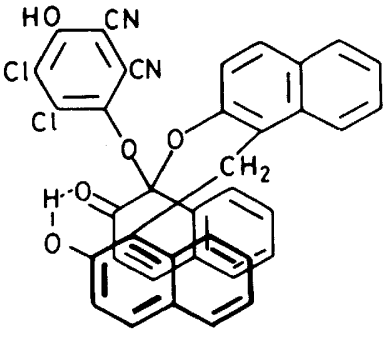

Figure 2.

(12a) and (12b). Oxidation of the cyanobisnaphthol (4e) gave only the spiroketone (5e).

A possible mechanism for the formation of these products from the oxidation of bisnaphthols is shown in Scheme 1. As in the case of $o$-chloranil oxidation, ${ }^{2}$ isolation of the quinonemethide dimer (6) in DDQ oxidation also indicates the gener- 
Table 3. The nature of the products formed in the oxidation of the bisnaphthols (4) with DDQ

\begin{tabular}{|c|c|c|c|c|c|}
\hline \multirow{2}{*}{$\begin{array}{l}\text { Compound } \\
\text { oxidised }\end{array}$} & \multirow{2}{*}{$\begin{array}{c}\text { Amount } \\
\text { (g) }\end{array}$} & \multicolumn{4}{|c|}{ Compounds isolated } \\
\hline & & (12) & (13) & (5) & (6) \\
\hline (4a) & 4.0 & $\begin{array}{l}(12 a) \\
\left(0.7^{a}\right.\end{array}$ & $\begin{array}{l}(\mathbf{1 3 a}) \\
(0.04)\end{array}$ & $\begin{array}{c}(\mathbf{5 a}) \\
(0.48)\end{array}$ & $\begin{array}{c}(6 a) \\
(0.44)\end{array}$ \\
\hline$(4 b)$ & 4.0 & $\begin{array}{l}\text { '12b) } \\
(0.6)\end{array}$ & $\begin{array}{l}(13 b) \\
(0.045)\end{array}$ & $\begin{array}{c}(5 b) \\
(0.4)\end{array}$ & $\begin{array}{c}(6 \mathrm{~b}) \\
(0.35)\end{array}$ \\
\hline (4c) & 4.12 & $\begin{array}{l}(12 c) \\
(0.6)\end{array}$ & $\begin{array}{l}(13 c) \\
(0.02)\end{array}$ & $\begin{array}{c}(5 c) \\
(0.45)\end{array}$ & $\begin{array}{c}(6 c) \\
(0.4)\end{array}$ \\
\hline (4d) & 3.0 & $\begin{array}{l}(12 d) \\
(0.15)\end{array}$ & - & $\begin{array}{l}(\mathbf{5 d}) \\
(1.0)\end{array}$ & $\begin{array}{l}(\mathbf{6 d}) \\
(0.3)\end{array}$ \\
\hline (4e) & 0.5 & - & - & $\begin{array}{l}(5 \mathbf{5}) \\
(0.3)\end{array}$ & - \\
\hline (4f) & 1.5 & $\begin{array}{c}(12 \mathrm{e}) \\
(0.14) \\
(12 \mathrm{f}) \\
(0.1)\end{array}$ & - & - & $\begin{array}{c}(\mathbf{6 a}) \\
(0.04) \\
(\mathbf{6 b}) \\
(0.05) \\
(\mathbf{6 c}) \\
(0.045)\end{array}$ \\
\hline$(4 a)+(4 b)$ & $\begin{array}{c}0.3+0.46 \\
(1: 1 \\
\text { molar ratio })\end{array}$ & $\begin{array}{l}(12 \mathbf{a}) \\
(0.06) \\
(12 \mathbf{b}) \\
(0.04) \\
(12 \mathbf{g}) \\
(0.085)\end{array}$ & - & - & - \\
\hline
\end{tabular}

ation of 1,2-naphthoquinone 1-methide (9) as an intermediate. The initial step may be the formation of the quinol ether (22) similar to that formed in $o$-chloranil oxidation. The formation and disproportionation of quinol ethers are well documented in the literature. ${ }^{7-15}$ The quinol ether (22) could disproportionate to give the $o$-quinonemethide (9) [which leads to the dimer (6a)] and the oxydiphenol (23). The oxydiphenol (23) may undergo an intermolecular crossed oxidative coupling with the bisnaphthol (4a) in the presence of DDQ to give another quinol ether (24), which may undergo disproportionation to give the dispironaphthalenones (12a) and (13a). ${ }^{*}$ The spironaphthalenone (5a) is formed by direct intramolecular coupling of the bisnaphthol (4a). It should be mentioned that although quinol ethers are generally unstable above room temperature, their formation as transient species in refluxing benzene is not improbable. The formation of the monobromodispironaphthalenone (12e) and the dibromodispironaphthalenone (12f) in the oxidation of the monobromobisnaphthol (4f) is readily understandable by this mechanism.

As mentioned before, oxidation of the cyanobisnaphthol (4e) with DDQ gave only the directly coupled spiroketone (5e). A similar observation was made in the case of the $o$-chloranil oxidation of (4e), which also gave only the spiroketone (5e). The absence of the other expected products in these two reactions may indicate that the intermediate quinol ethers (22) and (8) were not formed.

\section{Experimental}

All melting points are uncorrected. U.v. spectra were recorded on a Unicam SP 700A spectrometer and i.r. spectra (Nujol) were

\footnotetext{
* The cis-compound (12a) is formed in larger proportions than the trans-compound (13a) in this oxidation. The quinol ether (24) may have a conformation in which the carbonyl and the hydroxy groups are on the same side as shown in Figure 2, owing to stabilisation by intramolecular hydrogen bonding (Dreiding models). This particular conformation could lead to predominance of the cis-compound (12a).
}

recorded with a Perkin-Elmer 397 spectrophotometer. ${ }^{1} \mathbf{H}$ N.m.r. spectra were recorded either on a Varian T-60, a Varian HA-100, or a Brucker-WH-270 MHz F.T. n.m.r. spectrometer and ${ }^{13} \mathrm{C}$ n.m.r. spectra were recorded on a Brucker-WH-270 spectrometer at an operating frequency of $67.89 \mathrm{MHz}$. Chemical shifts $\left({ }^{1} \mathrm{H}\right.$ and $\left.{ }^{13} \mathrm{C}\right)$ are given as $\delta$ values (p.p.m.) relative to tetramethylsilane as internal standard. Ether refers to diethyl ether.

Oxidation of Bis(2-hydroxy-1-naphthyl)methane (4a).-A solution of the bisnaphthol $(\mathbf{4 a})^{16}(4.0 \mathrm{~g})$ in dry benzene $(300$ - $\mathrm{ml}$ ) was refluxed with DDQ $(3.3 \mathrm{~g})$ for $8 \mathrm{~h}$, avoiding exposure to light. The precipitated hydroquinone was filtered off after cooling. The filtrate was concentrated and chromatographed over neutral alumina. Elution with benzene gave a light yellow solution containing two compounds. The compounds were separated by preparative t.l.c. [silica gel, benzene-hexane $(1: 1)$ ] to give the known spironaphthalenone $(5 \mathrm{a})(480 \mathrm{mg})$ and the quinone methide dimer (6a) (440 mg).

Further elution with chloroform gave a dark yellow solution which on concentration followed by addition of a little hexane, gave yellow needles of cis-dispiro(naphthalene-1,2' $\left(1^{\prime} \mathrm{H}\right)$-naphtho[2,1-b]pyran-3',1"-naphthalene)-2(1H),2" $\left(1^{\prime \prime} \mathrm{H}\right)$-dione (12a) (700 mg), m.p. $170^{\circ} \mathrm{C}$ (Found: $\mathrm{C}, 84.8 ; \mathrm{H}, 4.7 \mathrm{C}_{31} \mathrm{H}_{20} \mathrm{O}_{3}$ requires $\mathrm{C}, 84.5 ; \mathrm{H}, 4.6 \%) ; v_{\max }$. Nujol) 1680 and $1660 \mathrm{~cm}^{-1}(2 \alpha, \beta$ unsaturated ketones); $\lambda_{\max }\left(\mathrm{CHCl}_{3}\right) 245$ (ع 23600$), 268$ (8 000), 280 (7 550), 290 (6 330), $316(6000), 334$ (4 660), and $360 \mathrm{~nm}$ (1 100); $\delta_{\mathrm{H}}\left(270 \mathrm{MHz} ; \mathrm{CDCl}_{3}\right) 3.79(2 \mathrm{H}$, 'AB quartet' centre, $\left.\Delta v_{\mathrm{AB}} 279.7 \mathrm{~Hz}, J_{\mathrm{AB}} 17.8 \mathrm{~Hz}\right), 5.84(1 \mathrm{H}, \mathrm{d}, J 10 \mathrm{~Hz}), 6.03$ $(1 \mathrm{H}, \mathrm{d}, J 10 \mathrm{~Hz}), 6.36(1 \mathrm{H}, \mathrm{d}, J 7.6 \mathrm{~Hz}), 6.76-7.52(12 \mathrm{H}, \mathrm{m})$, and $7.8-7.9(3 \mathrm{H}, \mathrm{m}) ; \mathrm{m} / \mathrm{z} 440\left(\mathrm{M}^{+}\right)$. After crystallisation of compound (12a) the mother liquor was subjected to t.l.c. [silica gel, chloroform-hexane (4:1)]. The compound with lower $R_{f}$ value after crystallisation (chloroform-hexane) was transdispiro(naphthalene-1,2'(1'H)-naphtho[2,1-b]pyran-3',1"-naphthalene $]-2(1 \mathrm{H}), 2^{\prime \prime}\left(1^{\prime \prime} \mathrm{H}\right)$-dione (13a) $(40 \mathrm{mg})$, m.p. $171{ }^{\circ} \mathrm{C}$ (Found: $\mathrm{C}, 84.8 ; \mathrm{H}, 4.65 . \mathrm{C}_{31} \mathrm{H}_{20} \mathrm{O}_{3}$ requires $\mathrm{C}, 84.5 ; \mathrm{H}, 4.6 \%$ ); $v_{\text {max }}$ (Nujol) 1680 and $1660 \mathrm{~cm}^{1}(2 \alpha, \beta$-unsaturated ketones); $\lambda_{\text {max. }}\left(\mathrm{CHCl}_{3}\right) 245$ (ع 23600$), 268$ (8 000), 280 (7 550), 290 (6 330) $316(6000), 334(4660)$, and $360 \mathrm{~nm}(1100) ; \delta_{\mathrm{H}}(270 \mathrm{MHz}$; $\left.\mathrm{CDCl}_{3}\right) 3.61\left(2 \mathrm{H}\right.$, 'AB quartet' centre, $\Delta \mathrm{v}_{\mathrm{AB}} 35.7 \mathrm{~Hz}, J_{\mathrm{AB}} 17.3$ $\mathrm{Hz}), 5.57(1 \mathrm{H}, \mathrm{d}, J 10 \mathrm{~Hz}), 5.64(1 \mathrm{H}, \mathrm{d}, J 9.7 \mathrm{~Hz}), 6.69(1 \mathrm{H}, \mathrm{d}, J$ $10 \mathrm{~Hz}), 6.77(1 \mathrm{H}, \mathrm{d}, J 9.7 \mathrm{~Hz}), 7-7.6(11 \mathrm{H}, \mathrm{m})$, and $7.75-7.9(3$ $\mathrm{H}, \mathrm{m}) ; m / z 440\left(M^{+}\right)$.

Hydrogenation of Compound(12a).-A solution of compound (12a) $(300 \mathrm{mg})$ in ethyl acetate $(100 \mathrm{ml})$ was stirred with $10 \%$ $\mathrm{Pd}-\mathrm{C}$ catalyst $(50 \mathrm{mg})$ in an atmosphere of hydrogen until hydrogen uptake ceased $(12 \mathrm{~h})$. After filtering off the catalyst, the solvent was removed under reduced pressure and the residue crystallised from benzene-hexane to give colourless needles of 1-(2-hydroxy-1-naphthyl)methyl-2-(2-hydroxy-1-naphthyloxy)naphthalene (14) (250 mg), m.p. $127-128^{\circ} \mathrm{C}$ (Found: $\mathrm{C}$, 84.3; $\mathrm{H}, 5.1 \mathrm{C}_{31} \mathrm{H}_{22} \mathrm{O}_{3}$ requires $\mathrm{C}, 84.2 ; \mathrm{H}, 5.0 \%$ ); $v_{\max .}$ (Nujol) $3400-3500 \mathrm{~cm}^{1}(\mathrm{OH}) ; \delta_{\mathrm{H}}\left(270 \mathrm{MHz} ; \mathrm{CDCl}_{3}\right) 5.12(2 \mathrm{H}, \mathrm{s}$, $\left.\mathrm{CH}_{2}\right), 5.86\left(1 \mathrm{H}, \mathrm{s}, \mathrm{D}_{2} \mathrm{O}\right.$ exchangeable), $5.95\left(1 \mathrm{H}, \mathrm{s}, \mathrm{D}_{2} \mathrm{O}\right.$ exchangeable), $6.66(1 \mathrm{H}, \mathrm{d}, J 9.1 \mathrm{~Hz}), 6.97(1 \mathrm{H}, \mathrm{d}, J 9.1 \mathrm{~Hz}), 7.23$ $(1 \mathrm{H}, \mathrm{d}, J 9.1 \mathrm{~Hz}), 7.25-7.84(13 \mathrm{H}, \mathrm{m}), 8.12(1 \mathrm{H}, \mathrm{d}, J 8.1 \mathrm{~Hz})$, and $8.36(1 \mathrm{H}, \mathrm{d}, J 8.6 \mathrm{~Hz}) ; m / z 442\left(M^{+}\right)$.

Hydrogenation of Compound (13a).-A solution of compound (13a) $(50 \mathrm{mg})$ in ethyl acetate $(80 \mathrm{ml})$ was stirred with $10 \% \mathrm{Pd}-\mathrm{C}$ catalyst $(10 \mathrm{mg})$ in an atmosphere of hydrogen until hydrogen uptake ceased $(8 \mathrm{~h})$. After filtering off the catalyst, the solvent was removed under reduced pressure and the residue crystallised from benzene-hexane to give colourless needles of (14) (30 $\mathrm{mg}$ ) (identical with the product obtained in the previous experiment). 
Reduction of Compound (12a) with Zinc and Acetic Acid.Compound (12a) $(200 \mathrm{mg})$ in $50 \%$ aqueous acetic acid $(50 \mathrm{ml})$ was heated under reflux with zinc dust $(2.5 \mathrm{~g})$ for $3 \mathrm{~h}$. The hot solution was filtered and the zinc washed with a little methanol. The solvents were removed under reduced pressure. The reddish residue was recrystallised from benzene-hexane to give colourless needles of (14) $(120 \mathrm{mg})$ identical with the product obtained in the previous experiment).

Methylation of Compound (14).-A solution of compound (14) $(150 \mathrm{mg})$ in acetone $(75 \mathrm{ml})$ containing dimethyl sulphate $(0.5 \mathrm{ml})$ and fused potassium carbonate $(1 \mathrm{~g})$ was refluxed for 24 h. Potassium carbonate was filtered off. Removal of the solvent under reduced pressure and crystallisation of the residue from benzene-hexane gave colourless crystals of dimethyl ether (15) (100 mg), m.p. $160^{\circ} \mathrm{C}$ (Found: $\mathrm{C}, 84.1 ; \mathrm{H}$, 5.7. $\mathrm{C}_{33} \mathrm{H}_{26} \mathrm{O}_{3}$ requires $\mathrm{C}, 84.3 ; \mathrm{H}, 5.5 \%) ; \delta_{\mathrm{H}}\left(60 \mathrm{MHz} \mathrm{CDCl}_{3}\right) 3.6(3 \mathrm{H}$, s, $\left.\mathrm{OCH}_{3}\right), 3.8\left(3 \mathrm{H}, \mathrm{s}, \mathrm{OCH}_{3}\right), 5.1\left(2 \mathrm{H}, \mathrm{s}, \mathrm{CH}_{2}\right), 6.15(1 \mathrm{H}, \mathrm{d}, J 9$ $\mathrm{Hz}), 7.0-7.8(15 \mathrm{H}, \mathrm{m})$, and $8.0-8.4(2 \mathrm{H}, \mathrm{m}) ; m / z 470\left(M^{+}\right)$.

Benzylation of Compound (14).-A mixture of compound (14) $(100 \mathrm{mg})$ and powdered potassium hydroxide $(0.2 \mathrm{~g})$ in dry methanol $(10 \mathrm{ml})$ was refluxed on a water-bath for $15 \mathrm{~min}$. Benzyl chloride $(0.5 \mathrm{ml})$ was then added and refluxing was continued for $2 \mathrm{~h}$. The product was diluted with water, heated on a water-bath for $0.5 \mathrm{~h}$, and then extracted with ether. The ether solution was concentrated and the product was purified by t.l.c. [silica gel, benzene-hexane $(1: 1)$ ], to give a gummy sample of dibenzyl ether (16) (40 mg) which could not be crystallised (Found: $\mathrm{C}, 86.6 ; \mathrm{H}, 4.6 . \mathrm{C}_{45} \mathrm{H}_{34} \mathrm{O}_{3}$ requires $\mathrm{C}, 86.8 ; \mathrm{H}$, $5.5 \%) ; \delta_{\mathrm{H}}\left(60 \mathrm{MHz} ; \mathrm{CDCl}_{3}\right) 4.7\left(2 \mathrm{H}, \mathrm{s}, \mathrm{OCH}_{2} \mathrm{Ph}\right), 5.0(2 \mathrm{H}, \mathrm{s}$, $\left.\mathrm{OCH}_{2} \mathrm{Ph}\right), 5.2\left(2 \mathrm{H}, \mathrm{s}, \mathrm{CH}_{2}\right), 6.6(1 \mathrm{H}, \mathrm{d}, J 9 \mathrm{~Hz}), 6.8-7.8(25 \mathrm{H}$, $\mathrm{m})$, and $8.1-8.5(2 \mathrm{H}, \mathrm{m})$.

Synthesis of the Dimethyl Ether (15) by Ullmann Condensation.-A mixture of the monomethyl ether (19) of bis(2hydroxy-1-naphthyl)methane ${ }^{6}(5.4 \mathrm{~g})$, 1-bromo-2-methoxynaphthalene (21) $(1.4 \mathrm{~g})$, anhydrous potassium carbonate (3.0 g), and copper(II) oxide $(0.8 \mathrm{~g})$ was refluxed in dry pyridine under a nitrogen atmosphere on an oil-bath at $165 \pm 5^{\circ} \mathrm{C}$, for $44 \mathrm{~h}$. The pyridine was then distilled off and the residue was extracted with benzene. The benzene extract was washed successively with $5 \%$ aqueous $\mathrm{NaOH}$, water, $5 \% \mathrm{HCl}$, and water. The dried $\left(\mathrm{Na}_{2} \mathrm{SO}_{4}\right)$ extract was chromatographed over neutral alumina [hexane, benzene-hexane $(1: 2)]$. The hexane fraction on preparative t.l.c. (silica gel, hexane) gave 1-bromo-2-methoxynaphthalene (21) $(0.2 \mathrm{~g})$, m.p. $82^{\circ} \mathrm{C}$, and 2-methoxynaphthalene $(0.35 \mathrm{~g})$, m.p. $72^{\circ} \mathrm{C}$, identified by comparison with authentic samples. The benzene-hexane fraction gave a white solid $(400 \mathrm{mg})$ which on crystallisation from benzene-hexane gave $350 \mathrm{mg}$ of a pure dimethyl ether identical with the dimethyl ether (15) obtained earlier (mixed m.p. and i.r. and ${ }^{1} \mathrm{H}$ n.m.r. spectra).

Demethylation of the Dimethyl Ether (15) with $\mathrm{BBr}_{3} .-\mathrm{A}$ solution of $\mathrm{BBr}_{3}$ (supplied by Eastman Kodak Co.) $(0.5 \mathrm{ml})$ in dry methylene chloride $(5 \mathrm{ml})$ was added slowly to a solution of the dimethyl ether (15) $(200 \mathrm{mg})$ in dry methylene chloride (15 $\mathrm{ml}$ ), kept cool in a freezing chloroform bath. The mixture, protected from moisture, was stirred for $24 \mathrm{~h}$ (during the first 1 $h$ the cooling bath was maintained) at room temperature. Water was then added slowly with stirring and the mixture was extracted with chloroform. The dried, pink chloroform extract was concentrated and on t.l.c. (silica gel, chloroform) the dihydroxy compound (14) $(25 \mathrm{mg})$ was obtained. The other products isolated were the starting material (15) $(70 \mathrm{mg})$ and a compound $(10 \mathrm{mg})$ slightly less polar than (15) which was not identified.
Oxidation of Compound (14) with Active Manganese Dioxide.-A solution of compound (14) $(100 \mathrm{mg})$ in dry benzene was stirred with active manganese dioxide $(400 \mathrm{mg})$ for $12 \mathrm{~h}$. The black solid was filtered off and the solvent completely removed. Preliminary t.l.c. showed a single yellow compound with traces of starting material. Recrystallisation of the residue from chloroform-hexane gave compound (12a) $(85 \mathrm{mg}$ ) (identity confirmed by mixed m.p. and i.r. and ${ }^{1} \mathrm{H}$ n.m.r. spectra).

Oxidation of Compound (14) with $D D Q$.--A solution of compound (14) $(110 \mathrm{mg})$ was refluxed with DDQ $(60 \mathrm{mg})$ in dry benzene $(25 \mathrm{ml})$ for $8 \mathrm{~h}$. On preliminary t.l.c. the benzene solution, obtained after filtering off the hydroquinone, showed two yellow compounds. The solution was chromatographed over neutral alumina. Elution with chloroform gave a yellow solution from which compound (12a) $(60 \mathrm{mg}$ ) crystallised out on concentration and addition of a little hexane. The transisomer (13a) (10 mg) was isolated from the mother liquor by preparative t.l.c.

Oxidation of Bis(6-bromo-2-hydroxy-1-naphthyl)methane (4b) with $D D Q$.-A solution of the bisnaphthol $(\mathbf{4 b})^{16}(4.0 \mathrm{~g})$ was refluxed in dry benzene $(600 \mathrm{ml})$ with DDQ $(2.0 \mathrm{~g})$ for $10 \mathrm{~h}$. The precipitated hydroquinone was filtered off after cooling and the benzene solution was chromatographed over neutral alumina [benzene, benzene-chloroform (1:1)]. From the benzene fraction, the spironaphthalenone (5b) and quinone methide dimer (6b) were isolated by preparative t.l.c. [silica gel, benzenehexane (1:1)]. Compound (5b) crystallised as a bright yellow solid (400 mg) from benzene-hexane, m.p. $198-200^{\circ} \mathrm{C}$; $v_{\text {max. }}$ (Nujol) $1690 \mathrm{~cm}^{-1}$ ( $\alpha, \beta$-unsaturated ketone); $\delta_{\mathrm{H}}(60 \mathrm{MHz}$; $\left.\mathrm{CDCl}_{3}\right) 3.7\left(2 \mathrm{H}\right.$, 'AB quartet' centre, $\left.\Delta v_{\mathrm{AB}} 31.8 \mathrm{~Hz}, J_{\mathrm{AB}} 16 \mathrm{~Hz}\right)$, $6.2(1 \mathrm{H}, \mathrm{d}, J 9 \mathrm{~Hz}), 7.2-7.8(8 \mathrm{H}, \mathrm{m})$, and $8.0(1 \mathrm{H}, \mathrm{d}, J 2 \mathrm{~Hz})$. Compound (6b) crystallised as a dark yellow solid $(350 \mathrm{mg})$ from benzene-hexane, m.p. $176^{\circ} \mathrm{C}$ (lit., ${ }^{17} 177^{\circ} \mathrm{C}$ ); $v_{\max .}($ Nujol) $1675 \mathrm{~cm}^{1}(\alpha, \beta$-unsaturated ketone $) ; \delta_{\mathbf{H}}\left(60 \mathrm{MHz} ; \mathrm{CDCl}_{3}\right)$ $2.0-3.2\left(4 \mathrm{H}, \mathrm{m}, \mathrm{CH}_{2} \mathrm{CH}_{2}, 6.1(1 \mathrm{H}, \mathrm{d}, J 10 \mathrm{~Hz}), 7.1-7.6(8 \mathrm{H}\right.$, $\mathrm{m})$, and $7.8(1 \mathrm{H}, \mathrm{d}, J 2 \mathrm{~Hz})$. From the benzene-chloroform fraction the cis-tribromodispiro(naphthalenone $(\mathbf{1 2 b})$ crystallised out in the form of tiny crystals $(600 \mathrm{mg})$, m.p. $182^{\circ} \mathrm{C}$ (Found: C, $54.9 ; \mathrm{H}, 2.5 . \mathrm{C}_{31} \mathrm{H}_{17} \mathrm{O}_{3} \mathrm{Br}_{3}$ requires $\mathrm{C}, 55.0 ; \mathrm{H}, 2.5 \%$ ); $\nu_{\text {max. }}$ (Nujol) 1680 and $1660 \mathrm{~cm}^{-1}(2 \alpha, \beta$-unsaturated ketones); $\lambda_{\max .}\left(\mathrm{CHCl}_{3}\right) 247$ ( $\left.\mathrm{C}_{91} 900\right), 284$ (14 760), 294 (13 800), 310 (14 760), 344 (7 620), and $360 \mathrm{~nm}(4760) ; \delta_{\mathrm{H}}\left(270 \mathrm{MHz} ; \mathrm{CDCl}_{3}\right)$ $3.70\left(2 \mathrm{H}\right.$, 'AB quartet' centre, $\Delta \mathrm{v}_{\mathrm{AB}}\left(279.5 \mathrm{~Hz}, J_{\mathrm{AB}} 17.8 \mathrm{~Hz}\right), 5.98$ $(1 \mathrm{H}, \mathrm{d}, J 9.7 \mathrm{~Hz}), 6.08(1 \mathrm{H}, \mathrm{d}, J 9.7 \mathrm{~Hz}) .6 .27(1 \mathrm{H}, \mathrm{d}, J 7.8 \mathrm{~Hz})$, $6.82(1 \mathrm{H}, \mathrm{d}, J 9.7 \mathrm{~Hz}), 7.0-7.29(7 \mathrm{H}, \mathrm{m}), 7.55-7.73(3 \mathrm{H}, \mathrm{m})$, and $8.04(1 \mathrm{H}, \mathrm{d}, J 2 \mathrm{~Hz}) ; \mathrm{m} / z 674\left(M^{+}\right)$. After removal of compound $(\mathbf{1 2 b})$ t.l.c. [silica gel, chloroform-hexane $(6: 1)$ ] of the mother liquor gave the trans-isomer (13b) as yellow needles (45 mg), m.p. $175^{\circ} \mathrm{C}$ (Found: C, 55.1; H, 2.6. $\mathrm{C}_{31} \mathrm{H}_{13} \mathrm{Br}_{3} \mathrm{O}_{3}$ requires $\mathrm{C}, 55.0 ; \mathrm{H}, 2.5^{\circ}$ ); $v_{\max }$ (Nujol) 1685 and $1665 \mathrm{~cm}^{-1}(2$ $\alpha, \beta$-unsaturated ketones); $\lambda_{\max .}\left(\mathrm{CHCl}_{3}\right) 246$ ( $\left.\varepsilon 68750\right), 270$ (15 000), 280 (14 160), 296 (12 500), 328 (8 750), 346 (5 830), and $360 \mathrm{~nm}(3 \mathrm{330}) ; \delta_{\mathrm{H}}\left(270 \mathrm{MHz} ; \mathrm{CDCl}_{3}\right) 3.51$ (2 H, 'AB quartet' centre, $\left.\Delta v_{\mathrm{AB}} 36.5 \mathrm{~Hz}, J_{\mathrm{AB}} 17.3 \mathrm{~Hz}\right), 5.65(1 \mathrm{H}, \mathrm{d}, J 10 \mathrm{~Hz}), 5.71(1$ $\mathrm{H}, \mathrm{d}, J 9.7 \mathrm{~Hz}), 6.71(1 \mathrm{H}, \mathrm{d}, J 9.7 \mathrm{~Hz}), 6.77(1 \mathrm{H}, \mathrm{d}, J 10 \mathrm{~Hz})$, $7.22-7.7(10 \mathrm{H}, \mathrm{m})$, and $8.02(1 \mathrm{H}, \mathrm{d}, J 2 \mathrm{~Hz}) ; m / z 674\left(M^{+}\right)$.

Bis(6-t-butyl-2-hydroxy-1-naphthyl)methane (4c).--Formaldehyde $(40 \%$ aqueous; $1.75 \mathrm{ml})$ was added to a solution of sodium sulphite $(6.3 \mathrm{~g})$ in water $(25 \mathrm{ml})$ containing 6-t-butyl-2naphthol ${ }^{18}(6.4 \mathrm{~g})$ in suspension. This was heated $(20 \mathrm{~min}$, $100^{\circ} \mathrm{C}$ ) and the precipitate obtained was filtered off Recrystallisation from benzene-hexane gave the bisnaphthol (4c) $\left(3 \mathrm{~g}\right.$ ), m.p. $198-200{ }^{\circ} \mathrm{C}$ (Found: C, 84.3; $\mathrm{H}, 7.9 . \mathrm{C}_{29} \mathrm{H}_{32} \mathrm{O}_{2}$ requires $\mathrm{C}, 84.4 ; \mathrm{H}, 7.8 \%$ ); $v_{\max }$. $(\mathrm{Nujol}) 3300-3400 \mathrm{~cm}^{-1}$ 
$(\mathrm{OH}) ; \delta_{\mathrm{H}}\left(100 \mathrm{MHz} ; \mathrm{CDCl}_{3}\right) 1.4\left(18 \mathrm{H}, \mathrm{s}, 2 \mathrm{Bu}^{\prime}\right), 4.54(2 \mathrm{H}, \mathrm{s}$, $\left.\mathrm{CH}_{2}\right), 6.8-8.0(10 \mathrm{H}, \mathrm{m})$, and $9.2\left(2 \mathrm{H}, \mathrm{s}, \mathrm{D}_{2} \mathrm{O}\right.$ exchangeable $)$.

Oxidation of Bis(6-t-butyl-2-hydroxy-1-naphthyl)methane (4c).-A solution of the bisnaphthol $(4 \mathrm{c})(4.12 \mathrm{~g})$ in dry benzene $(400 \mathrm{ml})$ was refluxed with DDQ $(2.27 \mathrm{~g})$ for $10 \mathrm{~h}$. The precipitated hydroquinone was filtered off after cooling and the mixture was chromatographed over neutral alumina. Elution with benzene gave a light yellow solution containing two compounds. The compounds were separated by preparative t.l.c. [silica gel, benzene-hexane $(1: 1)$ ] and identified as the di-tbutylspironaphthalenone (5c) (450 mg), m.p. $120^{\circ} \mathrm{C}$ (Found: $\mathrm{C}$, 84.75; $\mathrm{H}, 7.3 \mathrm{C}_{29} \mathrm{H}_{30} \mathrm{O}_{2}$ requires $\mathrm{C}, 84.8 ; \mathrm{H}, 7.4 \%$ ); $v_{\max }$ (Nujol) $1680 \mathrm{~cm}^{1}\left(\alpha, \beta\right.$-unsaturated ketone); $\delta_{\mathrm{H}}\left(100 \mathrm{MHz} ; \mathrm{CDCl}_{3}\right)$ $1.30\left(9 \mathrm{H}, \mathrm{s}, \mathrm{Bu} \mathrm{u}^{\mathrm{l}}\right), 1.38(9 \mathrm{H}, \mathrm{s}, \mathrm{Bu}), 3.73(2 \mathrm{H}$, 'AB quartet' centre, $\left.\Delta v_{\mathrm{AB}} 54 \mathrm{~Hz}, J_{\mathrm{AB}} 16 \mathrm{~Hz}\right), 6.19(1 \mathrm{H}, \mathrm{d}, J 10 \mathrm{~Hz})$, and $7.2-7.9(9 \mathrm{H}$, $\mathrm{m}) ; m / z 410\left(M^{+}\right)$and di-t-butyl quinone methide dimer $(6 \mathrm{c})(400$ mg), m.p. $218{ }^{\circ} \mathrm{C}$ (decomp.) (Found: C, 85.0; $\mathrm{H}, 7.65 . \mathrm{C}_{30} \mathrm{H}_{32} \mathrm{O}_{2}$ requires $\mathrm{C}, 84.9 ; \mathrm{H}, 7.6 \%) ; v_{\max .}(\mathrm{Nujol}) 1675 \mathrm{~cm}^{-1}(\alpha, \beta-$ unsaturated ketone); $\delta_{\mathrm{H}}\left(100 \mathrm{MHz} \mathrm{CDCl}_{3}\right) 1.30\left(9 \mathrm{H}, \mathrm{s}, \mathrm{Bu}^{\mathrm{t}}\right)$, $1.37\left(9 \mathrm{H}, \mathrm{s}, \mathrm{Bu}^{\prime}\right), 1.93-3.15\left(4 \mathrm{H}, \mathrm{m}, \mathrm{CH}_{2} \mathrm{CH}_{2}\right), 6.05(1 \mathrm{H}, \mathrm{d}, J$ $10 \mathrm{~Hz})$, and $7.12-7.84(9 \mathrm{H}, \mathrm{m}) ; \mathrm{m} / z 424\left(M^{+}\right)$.

Further elution with chloroform gave a dark yellow solution from which cis-tri-t-butylbispironaphthalenone $(12 \mathrm{c})(600 \mathrm{mg})$ crystallised on addition of hexane, m.p. $183^{\circ} \mathrm{C}$ (Found: C, 84.7; $\mathrm{H}, 7.2 . \mathrm{C}_{43} \mathrm{H}_{44} \mathrm{O}_{3}$ requires $\mathrm{C}, 84.9 ; \mathrm{H}, 7.3 \%$ ); $v_{\text {max. }}$ (Nujol) 1690 and $1670 \mathrm{~cm}^{-1}\left(2 \alpha, \beta\right.$-unsaturated ketones); $\delta_{\mathrm{H}}\left(270 \mathrm{MHz} ; \mathrm{CDCl}_{3}\right)$ $1.26\left(18 \mathrm{H}, \mathrm{s}, 2 \mathrm{Bu}^{\mathrm{t}}\right), 1.44\left(9 \mathrm{H}, \mathrm{s}, \mathrm{Bu}^{\mathrm{t}}\right), 3.79$ (2 H, 'AB quartet' centre, $\left.\Delta v_{\mathrm{AB}} 274.5 \mathrm{~Hz}, J_{\mathrm{AB}} 18 \mathrm{~Hz}\right), 5.80(1 \mathrm{H}, \mathrm{d}, J 10 \mathrm{~Hz}), 5.99(1 \mathrm{H}, \mathrm{d}$, $J 10 \mathrm{~Hz}), 6.21(1 \mathrm{H}, \mathrm{d}, J 7.8 \mathrm{~Hz}), 6.6-7.26(8 \mathrm{H}, \mathrm{m})$, and $7.59-$ $7.84(4 \mathrm{H}, \mathrm{m}) ; m / z 608\left(M^{+}\right)$. T.l.c. (silica gel, chloroformhexane) of the mother liquor obtained after removal of compound $(12 \mathrm{c})$ gave the trans-isomer $(13 \mathrm{c})(20 \mathrm{mg}), \mathrm{m} . \mathrm{p} .185^{\circ} \mathrm{C}$ (Found: $\mathrm{C}, 84.75 ; \mathrm{H}, 7.25 . \mathrm{C}_{43} \mathrm{H}_{44} \mathrm{O}_{3}$ requires $\mathrm{C}, 84.9 ; \mathrm{H}, 7.3 \%$ ); $v_{\text {max }}$. (Nujol) 1680 and $1660 \mathrm{~cm}^{-1}(2 \alpha, \beta$-unsaturated ketones); $\delta_{\mathrm{H}}\left(270 \mathrm{MHz} ; \mathrm{CDCl}_{3}\right) 1.28\left(18 \mathrm{H}, \mathrm{s}, 2 \mathrm{Bu}^{\mathrm{t}}\right), 1.5\left(9 \mathrm{H}, \mathrm{s}, \mathrm{Bu}^{\mathrm{t}}\right), 3.58$ $\left(2 \mathrm{H}\right.$, 'AB quartet' centre, $\left.\Delta v_{\mathrm{AB}} 35.5 \mathrm{~Hz}, J_{\mathrm{AB}} 17.2 \mathrm{~Hz}\right), 5.6(1 \mathrm{H}, \mathrm{d}$, $J 10 \mathrm{~Hz}), 5.65(1 \mathrm{H}, \mathrm{d}, J 9.7 \mathrm{~Hz}), 6.68(1 \mathrm{H}, \mathrm{d}, 10 \mathrm{~Hz}), 6.76(1 \mathrm{H}, \mathrm{d}$, $J 9.7 \mathrm{~Hz})$, and $7.0-8.0(11 \mathrm{H}, \mathrm{m}) ; \mathrm{m} / z 608\left(M^{+}\right)$.

Bis(6-methoxy-2-hydroxy-1-naphthyl)methane

(4d).Formaldehyde (aqueous $40 \% ; 8.75 \mathrm{ml}$ ) was added to a solution of sodium sulphite $(31.5 \mathrm{~g})$ in water $(125 \mathrm{ml})$ containing 6-methoxy-2-naphthol ${ }^{19}(21.8 \mathrm{~g})$ in suspension. The mixture was heated $\left(30 \mathrm{~min}, 100^{\circ} \mathrm{C}\right)$ and the precipitate obtained was filtered off. Recrystallisation from acetic acid gave colourless crystals of the bisnaphthol (4d) $(8 \mathrm{~g})$, m.p. $220-222^{\circ} \mathrm{C}$ (Found: $\mathrm{C}, 84.2 ; \mathrm{H}, 6.0 . \mathrm{C}_{23} \mathrm{H}_{20} \mathrm{O}_{4}$ requires $\mathrm{C}, 84.1 ; \mathrm{H}, 6.1 \%$ ); $v_{\max .}$ (Nujol) $3400 \mathrm{~cm}^{-1}(\mathrm{OH}) ; \delta_{\mathrm{H}}\left[60 \mathrm{MHz} ;\left(\mathrm{CD}_{3}\right)_{2} \mathrm{SO}\right] 3.69\left(6 \mathrm{H}, \mathrm{s}, \mathrm{OCH}_{3}\right)$, $4.69\left(2 \mathrm{H}, \mathrm{s}, \mathrm{CH}_{2}\right), 6.69-7.41(8 \mathrm{H}, \mathrm{m}), 8.06(2 \mathrm{H}, \mathrm{d}, J 9 \mathrm{~Hz})$, and $9.35\left(2 \mathrm{H}, \mathrm{s}, \mathrm{D}_{2} \mathrm{O}\right.$ exchangeable $)$.

Oxidation of Bis(6-methoxy-2-hydroxy-1-naphthyl)methane (4d) with $D D Q$.-A solution of (4d) $(3.0 \mathrm{~g})$ in dry benzene $(700$ $\mathrm{ml})$ was refluxed with DDQ $(2.2 \mathrm{~g})$ for $18 \mathrm{~h}$. The precipitated hydroquinone was filtered off and the filtrate chromatographed over neutral alumina. Elution with benzene gave a light yellow solution containing two compounds. The compounds were separated by preparative t.l.c. [silica gel, benzene-hexane $(1: 1)$ ] and identified as the dimethoxyspironaphthalenone (5d) $(1.0 \mathrm{~g})$, m.p. $165^{\circ} \mathrm{C}$ (Found: $\mathrm{C}, 77.0 ; \mathrm{H}, 5.75 . \mathrm{C}_{23} \mathrm{H}_{18} \mathrm{O}_{4}$ requires $\mathrm{C}, 77.1$; $\mathrm{H}, 5.1 \%) ; v_{\max }$ (Nujol) $1660 \mathrm{~cm}^{-1}\left(\alpha, \beta\right.$-unsaturated ketone); $\delta_{\mathrm{H}}$ $\left(270 \mathrm{MHz} ; \mathrm{CDCl}_{3}\right) 3.75\left(2 \mathrm{H}\right.$, 'AB quartet' centre. $\Delta v_{\mathrm{AB}} 141.2$ $\left.\mathrm{Hz}, J_{\mathrm{AB}} 15.9 \mathrm{~Hz}\right), 3.83\left(3 \mathrm{H}, \mathrm{s}, \mathrm{OCH}_{3}\right), 3.90\left(3 \mathrm{H}, \mathrm{s}, \mathrm{OCH}_{3}\right), 6.25$ $(1 \mathrm{H}, \mathrm{d}, J 10 \mathrm{~Hz}), 6.86-7.46(8 \mathrm{H}, \mathrm{m})$, and $7.68(1 \mathrm{H}, \mathrm{d}, J 8.6 \mathrm{~Hz})$; $m / z 358\left(\mathrm{M}^{+}\right)$and the dimethoxy quinone methide dimer (6d) (300 mg), m.p. $147^{\circ} \mathrm{C}$ (Found: C, 77.45; H, 5.4. $\mathrm{C}_{24} \mathrm{H}_{20} \mathrm{O}_{4}$ requires $\mathrm{C}, 77.4 ; \mathrm{H}, 5.4 \%) ; v_{\max }(\mathrm{Nujol}) 1660 \mathrm{~cm}^{-1}(\alpha, \beta-$ unsaturated ketone); $\delta_{\mathrm{H}}\left(60 \mathrm{MHz} ; \mathrm{CDCl}_{3}\right) 2.0-3.3(4 \mathrm{H}, \mathrm{m}$, $\left.\mathrm{CH}_{2} \mathrm{CH}_{2}\right), 3.8\left(3 \mathrm{H}, \mathrm{s}, \mathrm{OCH}_{3}\right), 3.89\left(3 \mathrm{H}, \mathrm{s}, \mathrm{OCH}_{3}\right), 6.15(1 \mathrm{H}, \mathrm{d}$, $J 10 \mathrm{~Hz}), 6.9-7.4(8 \mathrm{H}, \mathrm{m})$, and $7.6(1 \mathrm{H}, \mathrm{d}, J 7.5 \mathrm{~Hz}) ; \mathrm{m} / \mathrm{z} 372$ $\left(M^{+}\right)$.

Further elution with chloroform gave a dark yellow solution from which cis-trimethoxybispironaphthalenone (12d) separated out as dark yellow needles $\left(150 \mathrm{mg}\right.$ ), m.p. $180-181^{\circ} \mathrm{C}$ (Found: C, $77.1 ; \mathrm{H}, 5.1 . \mathrm{C}_{34} \mathrm{H}_{26} \mathrm{O}_{6}$ requires $\mathrm{C}, 77.0 ; \mathrm{H}, 4.9 \%$ ); $v_{\max .}$ (Nujol) 1675 and $1690 \mathrm{~cm}^{-1}\left(2 \alpha, \beta\right.$-unsaturated ketones); $\delta_{\mathrm{H}}(270 \mathrm{MHz}$; $\left.\mathrm{CDCl}_{3}\right) 3.71\left(2 \mathrm{H}\right.$, 'AB quartet' centre, $\Delta v_{\mathrm{AB}} 280.3 \mathrm{~Hz}, J_{\mathrm{AB}} 17.8$ $\mathrm{Hz}), 3.75\left(3 \mathrm{H}, \mathrm{s}, \mathrm{OCH}_{3}\right), 3.77\left(3 \mathrm{H}, \mathrm{s}, \mathrm{OCH}_{3}\right), 3.94(3 \mathrm{H}, \mathrm{s}$, $\left.\mathrm{OCH}_{3}\right), 5.85(1 \mathrm{H}, \mathrm{d}, J 10 \mathrm{~Hz}), 6.01(1 \mathrm{H}, \mathrm{d}, J 10 \mathrm{~Hz}), 6.26-6.6(5$ $\mathrm{H}, \mathrm{m}), 6.79(1 \mathrm{H}, \mathrm{d}, J 9.5(\mathrm{~Hz}), 7.01(1 \mathrm{H}, \mathrm{d}, J 10 \mathrm{~Hz}), 7.15-7.22$ $(4 \mathrm{H}, \mathrm{m}), 7.67(1 \mathrm{H}, \mathrm{d}, J 8.6 \mathrm{~Hz})$, and $7.77(1 \mathrm{H}, \mathrm{d}, J 8.6(\mathrm{~Hz}) ; \mathrm{m} / z$ $530\left(M^{+}\right)$.

Oxidation of 6-Bromobis(2-hydroxy-1-naphthyl)methane (4f) with $D D Q$.-A solution of the bisnaphthol $(4 \mathrm{f})^{16}(1.5 \mathrm{~g})$ in dry benzene $(100 \mathrm{ml})$ was refluxed with DDQ $(0.5 \mathrm{~g})$ for $10 \mathrm{~h}$. The precipitated hydroquinone was filtered off and the benzene solution chromatographed over neutral alumina [benzene, benzene-chloroform $(1: 1)]$. The benzene fraction on repeated preparative t.l.c. gave three yellow compounds which were identifed as (6a) $(40 \mathrm{mg})$ and $(6 \mathrm{~b})(50 \mathrm{mg})$ by comparison with authentic samples and (6e), m.p. $165^{\circ} \mathrm{C}$ (Found: $\mathrm{C}, 67.45 ; \mathrm{H}, 3.8$. $\mathrm{C}_{22} \mathrm{H}_{15} \mathrm{BrO}_{2}$ requires $\mathrm{C}, 67.5 ; \mathrm{H}, 3.9 \%$; $v_{\max }$ (Nujol) $1680 \mathrm{~cm}^{-1}$ $\left(\alpha, \beta\right.$-unsaturated ketone); $\delta_{\mathrm{H}}\left(60 \mathrm{MHz} ; \mathrm{CDCl}_{3}\right) 2.0-3.0(4 \mathrm{H}$, $\left.\mathrm{m}, \mathrm{CH}_{2} \mathrm{CH}_{2}\right), 6.0(1 \mathrm{H}, \mathrm{d}, J 9 \mathrm{~Hz}), 7.1-7.7(9 \mathrm{H}, \mathrm{m})$ and $7.8(1 \mathrm{H}$, d, $J 2 \mathrm{~Hz}) ; m / z 390\left(M^{+}\right)$.

The chloroform fraction on preparative t.l.c. [silica gel, chloroform-hexane $(3: 1)]$ gave two compounds. The more polar compound, a yellow crystalline solid, was identified as the monobromobispironaphthalenone (12e) $(140 \mathrm{mg})$, m.p. $192{ }^{\circ} \mathrm{C}$ (Found: $\mathrm{C}, 71.7 ; \mathrm{H}, 3.5 . \mathrm{C}_{31} \mathrm{H}_{19} \mathrm{BrO}_{3}$ requires $\mathrm{C}, 71.7 ; \mathrm{H}, 3.7 \%$ ); $v_{\max }$ (Nujol) 1660 and $1680 \mathrm{~cm}^{-1}\left(2 \alpha, \beta\right.$-unsaturated ketones); $\delta_{\mathbf{H}}$ $\left(270 \mathrm{MHz} ; \mathrm{CDCl}_{3}\right) 3.74\left(2 \mathrm{H}\right.$, 'AB quartet' centre, $\Delta v_{\mathrm{AB}} 291 \mathrm{~Hz}$, $\left.J_{\mathrm{AB}} 17.8 \mathrm{~Hz}\right), 5.85(1 \mathrm{H}, \mathrm{d}, J 9.7 \mathrm{~Hz}), 6.02(1 \mathrm{H}, \mathrm{d}, J 10 \mathrm{~Hz}), 6.3(1$ $\mathrm{H}, \mathrm{d}, J 7.8(\mathrm{~Hz}), 6.76-7.26(10 \mathrm{H}, \mathrm{m}), 7.56-7.77(3 \mathrm{H}, \mathrm{m})$, and $8.04(1 \mathrm{H}, \mathrm{d}, J 2 \mathrm{~Hz}) ; m / z 518\left(M^{+}\right)$. The less polar compound, a yellow solid, was identified as the dibromobispironaphthalenone (12f) $(100 \mathrm{mg})$, m.p. $180^{\circ} \mathrm{C}$ (Found: C, 62.3; H, 2.6. $\mathrm{C}_{31} \mathrm{H}_{18} \mathrm{O}_{3} \mathrm{Br}_{2}$ requires $\mathrm{C}, 62.4 ; \mathrm{H}, 2.7 \%$ ); $v_{\max .}$ (Nujol) 1660 and $1680 \mathrm{~cm}^{-1}$ ( 2 $\alpha, \beta$-unsaturated ketones); $\delta_{\mathrm{H}}\left(270 \mathrm{MHz} ; \mathrm{CDCl}_{3}\right.$ ) $3.74\left(2 \mathrm{H}\right.$, 'AB quartet' centre, $\left.\Delta v_{\mathrm{AB}} 279.5 \mathrm{~Hz}, J_{\mathrm{AB}} 17.8 \mathrm{~Hz}\right), 5.88$ $(1 \mathrm{H}, \mathrm{d}, J 10 \mathrm{~Hz}), 6.06(1 \mathrm{H}, \mathrm{d}, J 10 \mathrm{~Hz}), 6.18(1 \mathrm{H}, \mathrm{d}, J 8.3 \mathrm{~Hz})$, 6.87-7.3 $(9 \mathrm{H}, \mathrm{m}), 7.56-7.75(3 \mathrm{H}, \mathrm{m})$, and $8.04(1 \mathrm{H}, \mathrm{d}, J 2 \mathrm{~Hz})$; $m / z 596\left(M^{+}\right)$.

Oxidation of a 1:1 Molar Mixture of the Bisnaphthols (4a) and (4b) with $D D Q$.-A mixture of the bisnaphthol (4a) (300 mg), the dibromobisnaphthol (4b) $(460 \mathrm{mg})$, and DDQ $(500 \mathrm{mg})$ in dry benzene $(80 \mathrm{ml})$ was refluxed for $12 \mathrm{~h}$. The precipitated hydroquinone was filtered off and the filtrate was concentrated and chromatographed over neutral alumina (benzene, chloroform). No attempt was made to separate the compound in the benzene fraction. On repeated preparative t.l.c. [silica gel, chloroform-hexane $(5: 1)]$ the chloroform fraction gave three compounds which were identified as (12a) $(60 \mathrm{mg})$ and $(12 b)(40$ $\mathrm{mg}$ ) by comparison with authentic samples and $(12 \mathrm{~g})(85 \mathrm{mg})$, m.p. $173{ }^{\circ} \mathrm{C}$ (Found: $\mathrm{C}, 62.55 ; \mathrm{H}, 2.80 . \mathrm{C}_{31} \mathrm{H}_{18} \mathrm{Br}_{2} \mathrm{O}_{3}$ requires $\mathrm{C}$, $62.4 ; \mathrm{H}, 2.7 \%) ; v_{\text {max. }}$ (Nujol) 1665 and $1680 \mathrm{~cm}^{-1}$ (2 $\alpha, \beta$-unsaturated ketones); $\delta_{\mathrm{H}}\left(270 \mathrm{MHz} ; \mathrm{CDCl}_{3}\right) 3.72(2 \mathrm{H},(\mathrm{AB}$ quartet' centre, $\left.\Delta v_{\mathrm{AB}} 285.7 \mathrm{~Hz}, J_{\mathrm{AB}} 17.8 \mathrm{~Hz}\right), 5.85(1 \mathrm{H}, \mathrm{d}, J 9.7 \mathrm{~Hz}), 6.06$ $(1 \mathrm{H}, \mathrm{d}, J 9.7 \mathrm{~Hz}), 6.42(1 \mathrm{H}, \mathrm{d}, J 7.8 \mathrm{~Hz}), 6.71-7.29(9 \mathrm{H}, \mathrm{m})$, 7.57-7.74 (3 H, m), and $8.04(1 \mathrm{H}, \mathrm{d}, J 2 \mathrm{~Hz}) ; \mathrm{m} / z 596\left(M^{+}\right)$.

Bis(6-cyano-2-hydroxy-1-naphthyl)methane (4e).-A mixture of 6-cyano-2-naphthol ${ }^{20}(1.7 \mathrm{~g})$, sodium sulphite $(2.6 \mathrm{~g}$ in $20 \mathrm{ml}$ 
water), and formaldehyde (aqueous; $40 \% 1 \mathrm{~g}$ ) were heated at $100^{\circ} \mathrm{C}$ for $30 \mathrm{~min}$. with occasional shaking. The precipitated solid was filtered off, washed with hot water, and recrystallised from acetone-chloroform to give as pale yellow crystals compound (4e) (0.8 g), m.p. $225^{\circ} \mathrm{C}$ (Found: C, 78.75; H, 3.9; N, 7.9. $\mathrm{C}_{22} \mathrm{H}_{14} \mathrm{~N}_{2} \mathrm{O}_{2}$ requires $\mathrm{C}, 78.8 ; \mathrm{H}, 4.0 ; \mathrm{N}, 8.0 \%$ ); $v_{\max .}$ (Nujol) $3200-3400(\mathrm{OH})$ and $2225 \mathrm{~cm}^{-1}(\mathrm{CN}) ; \delta_{\mathrm{H}}[60 \mathrm{MHz}$; $\left.\left.\left(\mathrm{CD}_{3}\right)_{2} \mathrm{SO}\right]\right) 4.53\left(2 \mathrm{H}, \mathrm{s}, \mathrm{CH}_{2}\right), 5.3\left(2 \mathrm{H}, \mathrm{s}, \mathrm{OH}, \mathrm{D}_{2} \mathrm{O}\right.$ exchangeable), $7.06(2 \mathrm{H}, \mathrm{d}, J 7.06 \mathrm{~Hz}), 7.36(2 \mathrm{H}, \mathrm{dd}), 7.67(2 \mathrm{H}, \mathrm{d}$, $J 10 \mathrm{~Hz}), 7.97(2 \mathrm{H}, \mathrm{d}, J 2 \mathrm{~Hz})$, and $8.2(2 \mathrm{H}, \mathrm{d}, J 9 \mathrm{~Hz})$.

Oxidation of the Bisnaphthol (4e) with $D D Q$.-A solution of the bisnaphthol $(4 \mathrm{e})(500 \mathrm{mg})$ in dry benzene $(100 \mathrm{ml})$ was refluxed with DDQ $(350 \mathrm{mg})$ for $10 \mathrm{~h}$. The precipitated hydroquinone was filtered off and the filtrate concentrated and chromatographed over neutral alumina (preliminary t.l.c. test showed only one yellow product). Elution with ethyl acetate gave a yellow product, which was crystallised from acetonechloroform to give the dicyanospironaphthalenone (5e), m.p. $231{ }^{\circ} \mathrm{C}$ (Found: $\mathrm{C}, 79.45 ; \mathrm{H}, 3.55 ; \mathrm{N}, 8.1 . \mathrm{C}_{23} \mathrm{H}_{12} \mathrm{~N}_{2} \mathrm{O}_{2}$ requires $\mathrm{C}, 79.3 ; \mathrm{H}, 3.5 ; \mathrm{N}, 8.0 \%) ; v_{\max .}$ (Nujol) $2230(\mathrm{CN})$ and $1690 \mathrm{~cm}^{-1}$ $\left(x, \beta\right.$-unsaturated ketone); $\delta_{\mathrm{H}}\left[60 \mathrm{MHz} ;\left(\mathrm{CD}_{3}\right)_{2} \mathrm{SO}\right] 3.79(2 \mathrm{H}$, 'AB quartet' centre, $\left.\Delta v_{\mathrm{AB}} 34.1 \mathrm{~Hz}, J_{\mathrm{AB}} 15.6 \mathrm{~Hz}\right), 6.3(1 \mathrm{H}, \mathrm{d}, J 9$ $\mathrm{Hz}), 7.4(1 \mathrm{H}, \mathrm{d}, J 9 \mathrm{~Hz}), 7.57-8.03(7 \mathrm{H}, \mathrm{m})$, and $8.4(2 \mathrm{H}, \mathrm{s})$.

Oxidation of the Bisnaphthol (4e) with o-Chloranil.-A solution of the bisnaphthol $(4 \mathrm{e})(300 \mathrm{mg})$ in dry benzene $(100 \mathrm{ml})$ was refluxed with $o$-chloranil $(500 \mathrm{mg})$ for $15 \mathrm{~h}$. After concentration the reaction mixture was chromatographed over neutral alumina. Elution with ethyl acetate gave the dicyanospironaphthalenone (5e). No other products were isolated.

\section{References}

1 T. R. Kasturi, T. Arunachalam, and G. Subrahmanyam, J. Chem. Soc. C, 1970, 1257.

2 T. R. Kasturi, B. Rajashekhar, and R. Sivaramakrishnan, Indian J. Chem., Sect. B, 1979, 18, 1.

3 T. R. Kasturi, B. Rajashekhar, G. J. Raju, R. Sivaramakrishnan, N. Ramasubbu, and K. Venkatesan, J. Chem. Soc., Chem. Commun., 1980, 1087.

4 'International tables for X-ray Crystallography, vol. III, 1968, Kynoch Press, Birmingham, p. 276.

5 D. G. Herwitt, J. Chem. Soc. C, 1971, 1750.

6 W. J. Evans and S. Smiles, J. Chem. Soc., 1937, 727.

7 H. D. Becker, J. Org. Chem., 1965, 30, 982.

8 H. D. Becker, J. Org. Chem., 1969, 34, 1203.

9 D. A. Bolon, J. Org. Chem., 1970, 35, 715.

10 D. G. Herwitt, J. Chem. Soc. C, 1971, 1750

11 A. W. S. Dick, F. M. Dean, D. A. Matkin, and M. L. Robinson, J. Chem. Soc., Perkin Trans. 1, 1977, 2204.

12 H. D. Becker, J. Org. Chem., 1969, 34, 1198.

13 M. Chauhan, F. M. Dean, K. Hindley, and M. L. Robinson, J. Chem. Soc., Chem. Commun., 1971, 1141.

14 M. F. Ansell and V. J. Leslie, J. Chem. Soc. C, 1971, 1423.

15 M. F. Ansell and V. J. Leslie, J. Chem. Soc., Chem. Commun., 1967, 949.

16 E. A. Shearing and S. Smiles, J. Chem. Soc., 1937, 1348.

17 R. Pummerer and E. Cherbuliez, Ber., 1919, 52, 1392; R. Pummerer and I. Veit, Chem. Ber., 1953, 86, 412.

18 NG. PH. Buu-Hoi, H. Le Bihan, F. Binon, and P. Rayet, J. Org. Chem., 1950, 15, 1061.

19 H. E. French and K. Sears, J. Am. Chem. Soc., 1948, 70, 1279.

20 F. H. S. Curd and C. G. Raison, J. Chem. Soc., 1947, 160.

Received 3rd January 1984; Paper 4/003 